\title{
Reação de imunofluorescência indireta para detecção de anticorpos anti-Neospora caninum em amostras coletivas de leite
}

\author{
Indirect fluorescent antibody test to detection of Neospora caninum antibodies in \\ samples of bulk milk
}

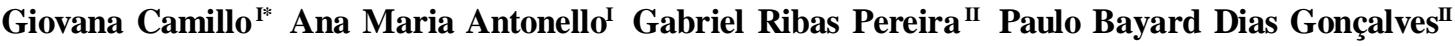 Luís Antônio SangioniI Lilian Muller ${ }^{\text {III }}$ Fernanda Silveira Flores Vogel ${ }^{\mathrm{I}}$}

\section{RESUMO}

\begin{abstract}
$O$ objetivo deste estudo foi determinar a presença de anticorpos anti-Neospora caninum em amostras coletivas de leite, através da reação de imunofluorescência indireta (RIFI). Para isso, foram coletadas amostras do leite dos tanques refrigerados de 36 rebanhos, das quais foram selecionadas 14 para coletas de amostras individuais de soro sanguíneo e de leite das vacas. Encontrou-se correlação em 12 dos 14 rebanhos selecionados para a amostragem individual dos animais, em comparação à detecção de anticorpos nas amostras coletivas de leite. Foi observada uma concordância de $76 \%$ comparando-se o resultado das amostras coletivas com os resultados individuais de leite. Observaram-se baixos títulos de anticorpos (50) no soro sanguíneo dos animais soropositivos, cujos resultados da RIFI no leite coletivo e no sangue foram discordantes. Assim, a partir dos resultados deste estudo, pode-se concluir que a utilização de testes sorológicos para detecção de anticorpos anti-N. caninum em amostras coletivas de leite através da RIFI pode ser uma opção ao diagnóstico para a triagem de rebanhos positivos bem como para estudos epidemiológicos.
\end{abstract}

Palavras-chave: RIFI, neosporose, rebanhos leiteiros, diagnóstico.

\section{ABSTRACT}

The aim of this study was to determine the presence of anti-N. caninum in the bulk milk samples by indirect immunofluorescence assay (IFAT). For this, it was collected samples of milk from refrigerated tanks from 36 herds, of which 14 were selected for sampling of individual blood serum and milk of cows. It was found concordance for 12 of the 14 herds selected for samples of individual animals, compared to the detection of antibodies in the bulk milk samples. Concordance was of $76 \%$ when comparing the results of the pooled sample with the results of individual milk. It was observed low antibody titers (50) in the serum of animals positive whose results in IFA of bulk milk and blood were discordant. Thus, with the results of this study, it can be concluded that the use of serological tests for detection of anti-N. caninum in the bulk milk samples from the IFAT could be an alternative diagnosis for the screening of positive herds as well as for epidemiological studies.

Key words: IFAT, neosporosis, dairy herds, diagnostic.

\section{INTRODUÇÃO}

A infecção pelo protozoário Neospora caninum (N. caninum) está amplamente distribuída em todo o mundo e é reconhecida como uma das maiores causas de aborto, contribuindo com importantes perdas econômicas, principalmente em bovinos de leite (DUBEY, 2003). O diagnóstico da neosporose é baseado, principalmente, na pesquisa de anticorpos anti- $\boldsymbol{N}$. caninum. Diferentes testes têm sido desenvolvidos para a detecção de anticorpos contra o protozoário em soro sanguíneo e amostras individuais e coletivas de leite (BJÖRKMAN \& UGGLA, 1999). Outros estudos também demonstram a utilização de amostras coletivas de leite de bovinos para a pesquisa de anticorpos contra outros agentes, como vírus (PRITCHARD, 2001), bactérias (NIELSEN et al., 2000)

IDepartamento de Medicina Veterinária Preventiva (DMVP), Centro de Ciências Rurais (CCR), Universidade Federal de Santa Maria (UFSM), 97105-900, Santa Maria, RS, Brasil. E-mail: giovanacamillo@yahoo.com.br. *Autor para correspondência.

IIDepartamento de Clínica de Grandes Animais (CGA), UFSM, Santa Maria, RS, Brasil.

"IIMédica Veterinária, Departamento Técnico da COSULATI, Pelotas, RS, Brasil. 
e helmintos (SANCHEZ et al., 2002). Atualmente, o principal método utilizado para o diagnóstico da neosporose a partir de amostras coletivas de leite é o ELISA (CHANLUN et al., 2006). Outro método bastante utilizado para detecção de anticorpos específicos é a reação de imunofluorêscencia indireta (RIFI), que já foi descrita como teste padrão para detecção de anticorpos anti-Neospora spp. em soro sanguíneo (PARÉ et al., 1995). Há poucos relatos com relação ao diagnóstico a partir de amostras de leite pela RIFI (OOI et al., 2000; CAMILLO et al., 2011). Esses estudos têm demonstrado boa concordância entre amostras positivas no soro sanguíneo e no leite.

Assim, o principal objetivo deste estudo é viabilizar a detecção de anticorpos anti-N. caninum em amostras coletivas de leite através da RIFI, relacionando com a análise sorológica individual dos animais de cada rebanho.

\section{MATERIAL E MÉTODOS}

Em um primeiro momento, foram coletadas amostras coletivas de leite de 36 propriedades leiteiras, escolhidas por conveniência, nas regiões central e sul do Rio Grande do Sul. Não foi levado em consideração o possível diagnóstico prévio de neosporose nesses rebanhos. Após a pesquisa de anticorpos anti- $N$. caninum pela RIFI (conforme a técnica descrita a seguir), foram selecionadas, pela disponibilidade dos produtores, 14 propriedades para uma nova amostragem individual de sangue e de leite de todas as vacas lactantes (totalizando 201 animais), bem como a coleta de uma amostra coletiva de leite de cada rebanho. $\mathrm{O}$ intervalo entre as duas coletas de amostras coletivas foi de 45 dias.

\section{Amostras}

Amostras coletivas de leite foram obtidas dos tanques de armazenamento, aproximadamente $15 \mathrm{~mL}$ por propriedade $(\mathrm{n}=36)$. Após a seleção dos 14 rebanhos, amostras de leite individuais $(n=201)$ foram coletadas de todos os animais em lactação em tubos de ensaio estéreis e as de sangue por meio de punção da veia coccígea em tubos de vacutainer. Foi também coletada uma nova amostra coletiva de leite de cada um dos quatorze rebanhos. As amostras de sangue e de leite foram centrifugadas (a 1000xg por 10min) para obtenção do soro e para extração da camada de gordura, respectivamente, sendo, em seguida, armazenadas $\mathrm{a}-20^{\circ} \mathrm{C}$.

Reação de Imunofluorescência Indireta (RIFI) A pesquisa de imunoglobulinas da classe $\mathrm{G}$ (IgG) contra o N. caninum no soro sanguíneo foi realizada pela RIFI conforme metodologia descrita por PARÉ et al. (1995). Foram consideradas positivas aquelas amostras nas quais se observou completa fluorescência da superfície dos taquizoítos de $N$. caninum a partir de uma diluição mínima de 1:50 em PBS. Determinou-se o título máximo da reação para cada uma das amostras de soro sanguíneo por meio de diluição seriada. As amostras de leite tanto individuais como coletivas não foram diluídas, seguindo técnica padronizada previamente (CAMILLO et al., 2011). Como anticorpo secundário, utilizou-se anti-IgG ${ }^{\odot a}$ bovina conjugada à fluoresceína. Amostras de soro sanguíneo ou de leite de bovinos, sabidamente positivas ou negativas, foram utilizadas como controle para a RIFI.

\section{Análise estatística}

As amostras de soro sanguíneo e de leite de cada vaca foram testadas paralelamente. Os resultados da detecção de anticorpos nos diferentes fluidos testados foram comparados utilizando-se os resultados da RIFI no soro sanguíneo como referência. As amostras coletivas foram comparadas com os resultados individuais de soro e/ou leite por rebanho. Assim, foram calculadas, seguindo as recomendações da OPAS (1997), a sensibilidade, a especificidade e a concordância (índice kappa) para a detecção de anticorpos nas amostras individuais e coletivas de leite pela RIFI.

\section{RESULTADOS E DISCUSSÃO}

Detectou-se a presença de anticorpos antiN. caninum em 91,7\% (33/36) dos rebanhos avaliados por amostragem coletiva de leite. Em virtude da alta frequência de detecção de anticorpos contra o protozoário na população estudada, ressalta-se a importância dessa infecção em bovinos. A partir da análise das amostras coletivas de leite, detectaram-se anticorpos anti-N. caninum em 78,5\% (11/14) dos rebanhos em que foram coletadas amostras individuais de sangue e de leite das vacas. Porém, a análise das amostras individuais demonstrou a presença de animais soropositivos em dois dos três rebanhos considerados negativos pela análise do leite proveniente dos tanques de armazenamento. A propriedade \# 13 (Tabela 1) apresentava uma vaca com título 50 para o soro sanguíneo e positiva na amostra individual de leite. Porém, deve-se ressaltar que o título encontrado neste animal foi de 50, o que é abaixo da diluição utilizada normalmente na rotina. Assim, se a diluição utilizada no soro sanguíneo fosse de 1:100, o resultado seria negativo e concordante. Da mesma forma, na propriedade \# 10, em cinco animais (5/10), foram 
Tabela 1 - Análise qualitativa de amostras coletivas de leite relacionadas ao total de positivas no soro sanguíneo e no leite e a variação dos títulos de anticorpos em cada propriedade.

\begin{tabular}{lcccc}
\hline Rebanho & $\begin{array}{c}\text { Amostras coletivas } \\
\text { de leite }\end{array}$ & $\begin{array}{c}\text { Amostras individuais de leite } \\
\text { Positivas/total }\end{array}$ & $\begin{array}{c}\text { Positivas no soro sanguíneo } \\
\text { /total }\end{array}$ & $\begin{array}{c}\text { Variação dos títulos de } \\
\text { anticorpos no soro sanguíneo }\end{array}$ \\
\hline 1 & + & $4 / 13$ & $5 / 13$ & $(50-800)$ \\
2 & + & $2 / 8$ & $2 / 8$ & $(100)$ \\
3 & + & $3 / 11$ & $4 / 11$ & $(50-800)$ \\
4 & + & $4 / 7$ & $4 / 7$ & $(100-200)$ \\
5 & + & $28 / 48$ & $29 / 48$ & $(50-800)$ \\
6 & + & $7 / 25$ & $16 / 25$ & $(50-800)$ \\
7 & + & $7 / 10$ & $7 / 10$ & $(100-400)$ \\
8 & - & $0 / 7$ & $0 / 7$ & $(<50)$ \\
9 & + & $5 / 25$ & $10 / 25$ & $(50-400)$ \\
10 & - & $0 / 11$ & $5 / 11$ & $(50)$ \\
11 & + & $2 / 12$ & $7 / 12$ & $(50-400)$ \\
12 & + & $7 / 10$ & $8 / 10$ & $(50-400)$ \\
13 & - & $1 / 4$ & $1 / 4$ & $(50)$ \\
14 & + & $1 / 10$ & $9 / 10$ & $(50)$ \\
\hline
\end{tabular}

detectados anticorpos apenas no soro, todos com título de 50. Em nenhum desses animais foram detectados anticorpos na amostra individual de leite.

Avaliando-se a totalidade dos animais, com relação ao soro sanguíneo, na maioria das vacas lactantes, foram detectados anticorpos contra o protozoário (107/201; 53,3\%). Em todos os rebanhos em que os animais apresentaram título de anticorpos =100 no soro sanguíneo foi possível a detecção de soropositividade em amostras coletivas de leite. A detecção de anticorpos em amostras coletivas de leite em rebanhos que apresentem poucos animais com títulos de anticorpos $=100$ pode estar condicionada, particularmente, a uma maior ou menor produção de leite desses animais em relação aos demais. Nesse sentido, BARTELS et al. (2007) analisaram amostras coletivas de leite durante um ano e meio e observaram que o principal fator atribuído para a flutuação dos níveis de anticorpos foi a proporção de animais soropositivos que contribuem com o volume do leite. Os títulos de anticorpos no leite podem variar conforme os níveis séricos de anticorpos, estágio de lactação, produção leiteira e presença de reações inflamatórias na glândula mamária, entre outros (PERINO et al., 1995). Dessa forma, pode-se esperar algum resultado falso positivo ou negativo a partir de amostras individuais e coletivas de leite. No entanto, nas amostras individuais de leite, essa probabilidade é menor, como demonstrado por CAMILLO et al. (2011).

Analisando os resultados obtidos a partir das amostras individuais de soro sanguíneo e de leite (Figura 1), semelhantemente ao encontrado por CAMILLO et al. (2011), pode-se observar que a frequência de animais com anticorpos detectáveis no leite aumenta conforme aumentam os títulos no soro sanguíneo. No presente estudo, dos animais com título de anticorpos séricos de 50 (47/201), a maioria foi negativo na amostra individual de leite (36/47). Dessa forma, a concordância entre as amostras com título de 50 foi de apenas $27 \%$ e a sensibilidade foi de $57 \%$. No entanto, considerando a detecção paralela de anticorpos no leite e soro sanguíneo da totalidade das amostras, obteve-se concordância de 64\%, sensibilidade de $74 \%$ e especificidade de $100 \%$. A sensibilidade da RIFI foi inferior ao índice de $90 \%$ relatado por CAMILLO et al. (2011), nessas mesmas condições, quando utilizou esse mesmo teste para detectar anticorpos em amostras individuais de leite. Quando analisada a correlação das amostras coletivas com as amostras individuais de leite, obteve-se $76 \%$ de concordância.

Sabe-se que determinados fatores afetam a sensibilidade e especificidade da RIFI, tais como a diluição e a concentração de anticorpos, o estádio de lactação, a amostragem (CHRISTENSEN \& GARDNER, 2000) e a produção de leite (STENLUND et al., 1999). Supondo-se que os níveis de anticorpos no leite refletem os níveis de anticorpos no soro sanguíneo (SCHARES et al., 2004), vacas no início da lactação têm níveis intermediários de anticorpos combinados com alta produção de leite, enquanto vacas que estão produzindo baixos volumes diários de leite apresentam concentração de anticorpos mais alta no leite. SANCHEZ et al. (2002) demonstraram, em um estudo com Ostertagia ostertagi, que os altos níveis de

Ciência Rural, v.41, n.9, set, 2011. 


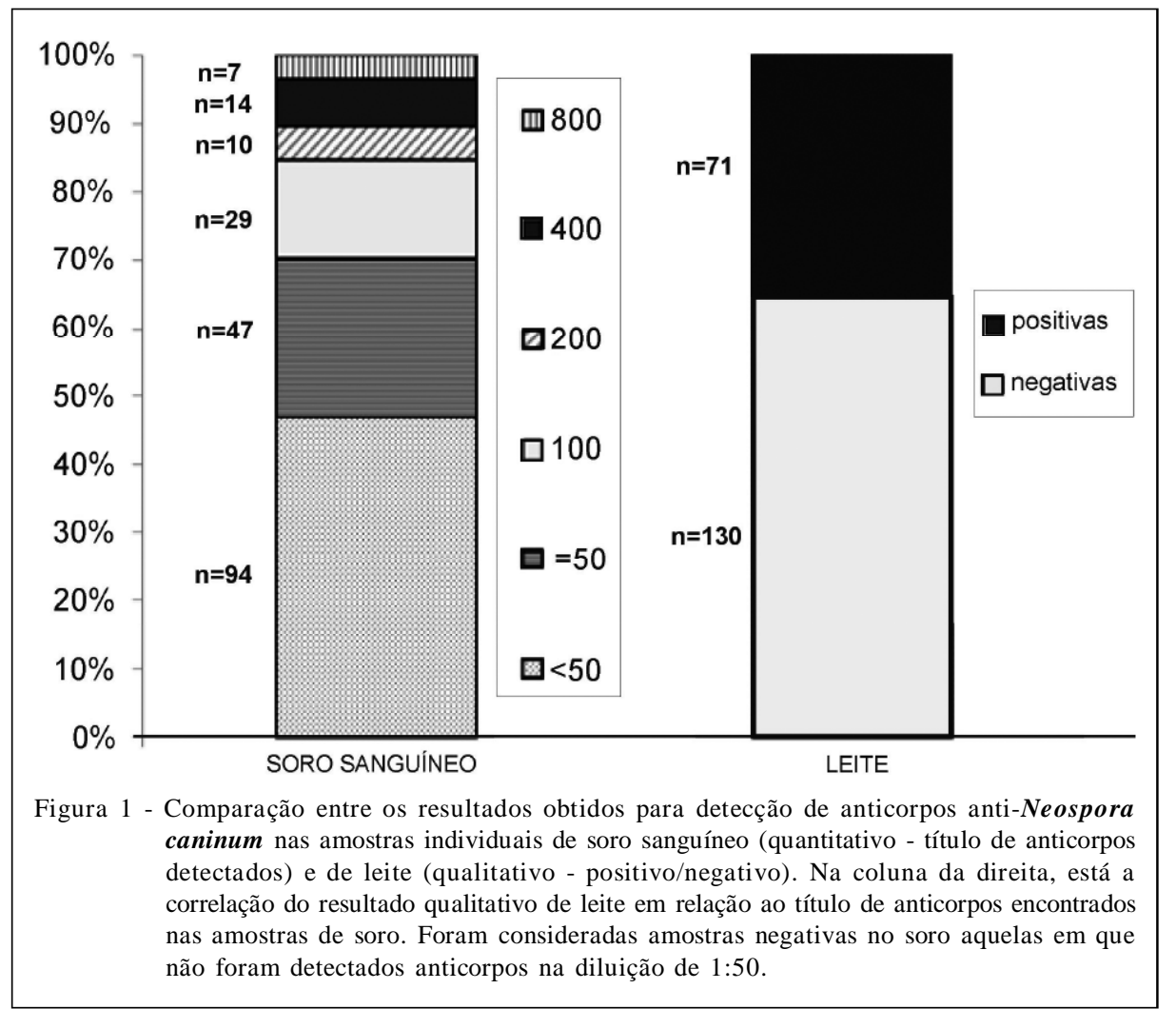

anticorpos encontrados em amostras coletivas de leite estão associados à baixa produção diária de leite.

CHANLUN et al. (2006) demonstraram, a partir de três coletas de amostras coletivas repetidas dos mesmos rebanhos, que os resultados de um único teste devem ser interpretados com cautela, uma vez que apenas as vacas em lactação contribuem para o status do rebanho. Além disso, em determinadas propriedades, as vacas infectadas podem ser descartadas por apresentarem outros problemas reprodutivos, sem que os proprietários saibam que são animais soropositivos para $N$. caninum (THURMOND \& HIETALA, 1996), o que pode contribuir para diminuir as chances de que amostras coletadas dos tanques permaneçam positivas ao longo do tempo.

Um resultado negativo em uma amostragem coletiva não exclui a presença da infecção por diversos fatores já discutidos anteriormente. Embora, neste trabalho, não se tenha verificado diferença na detecção de anticorpos anti- $\boldsymbol{N}$. caninum nas amostras dos mesmos tanques em um intervalo de 45 dias, pode-se preconizar que avaliações semestrais sejam realizadas para minimizar esses fatores anteriormente discutidos. A recomendação semestral deve-se à oscilação dos níveis de anticorpos presentes no soro de animais sabidamente positivos (CHANLUN et al., 2006).

\section{CONCLUSÃO}

Para o diagnóstico da neosporose, a detecção em amostras coletivas de leite é de grande importância, pela praticidade de coleta e pelos custos reduzidos deste tipo de avaliação em comparação ao processamento de amostras de cada vaca do rebanho. Pode-se utilizar esse tipo de procedimento para estudos epidemiológicos de bacias leiteiras ou regiões, obtendo-se uma boa estimativa da frequência mínima de rebanhos infectados nesses locais, podendo fornecer informações sobre a prevalência e distribuição dos rebanhos positivos para $N$. caninum. Nesse sentido, a utilização da RIFI pode ser uma opção ao diagnóstico.

\section{FONTES DE AQUISIÇÃO}

a - Anti-IgG ${ }^{\odot}$ bovina conjugada à fluoresceína (FITC): Affinity Purified Antibody Fluorescein. Clopper Road 910, Gaithersburg, MD 20878 USA. www.kpl.com.

\section{REFERÊNCIAS}

BARTELS, C.J.M. et al. Factors associated with variation in Neospora caninum bulk-milk S/P ratios in initially bulk-milk negative testing Dutch dairy herds. Preventive Veterinary Medicine, v.81, p.265-273, 2007. Disponível em: <http:// www.sciencedirect.com/science?_ob=ArticleURL\&_udi=B6TBK- 
4NYBM8G>. Acesso em: 16 nov. 2010. doi:10.1016/ j.prevetmed.2007.04.019.

BJÖRKMAN, C.; UGGLA, A. Serological diagnosis of Neospora caninum infection. International Journal for Parasitology, v.29, p.1497-1507, 1999. Disponível em: <http://www.sciencedirect.com/ science?_ob=ArticleURL\&_udi=B6T7F-3Y9HGBR>. Acesso em: 17 nov. 2010. doi:10.1016/S0020-7519(99)00115-0.

CAMILlO, G. et al. Detecção de anticorpos anti-Neospora caninum em amostras individuais e coletivas de leite de bovinos pela reação de imunofluorescência indireta (RIFI), Pesquisa Veterinária Brasileira, v.31, p.482-486, 2011. Disponível em: <http://www.pvb.com.br/pdf_artigos/23-06-2011_1621Vet\%20976_2161\%20LD.pdf>. Acesso em: 27 jun. 2011.

CHANLUN, A. et al. Application of repeated bulk milk testing for identification of infection dynamics of Neospora caninum in Thai dairy herds. Veterinary Parasitology, v.136, p.243250,2006. Disponível em: <http://www.sciencedirect.com/ science?_ob=ArticleURL\&_udi=B6TD7-4J022WT-3>. Acesso em: 17 nov. 2010. doi:10.1016/j.vetpar.2005.11.025.

CHRISTENSEN, J.; GARDNER, I.A. Herd-level interpretation of test results for epidemiologic studies of animal diseases. Preventive Veterinary Medicine, v.45, p.83-106, 2000. Disponível em: <http:/ /www.sciencedirect.com/science?_ob=ArticleURL\&_udi=B6TBK408BJCN-6>. Acesso em: 17 nov. 2010. doi:10.1016/S01675877(00)00118-5.

DUBEY, J.P. Review of Neospora caninum and neosporosis in animals. Korean Journal of Parasitology, v.41, n.1, p.116, 2003. Disponível em: <http://www.ncbi.nlm.nih.gov/pmc/ articles/PMC2717477/>. Acesso em: 16 nov. 2010. doi: 10.3347/kjp.2003.41.1.1.

NIELSEN, S.S. et al. Bulk tank milk ELISA antibodies for estimating the prevalence of paratuberculosis in Danish dairy herds. Preventive Veterinary Medicine, v.44, p.1-7, 2000. Disponível em: <http:/ /www.sciencedirect.com/science?_ob=ArticleURL\&_udi=B6TBK3YVD89C-1>. Acesso em: 17 nov. 2010. doi:10.1016/S01675877(00)00098-2.

OOI, H.K. et al. Serological survey and first finding of Neospora caninum in Taiwan, and the detection of its antibodies in various body fluids of cattle. Veterinary Parasitology, v.90, p.4755, 2000. Disponível em: <http://www.sciencedirect.com/
science?_ob=ArticleURL\&_udi=B6TD7-40BG4H5-5>. Acesso em: 17 nov. 2010. doi:10.1016/S0304-4017(00)00211-9.

OPAS (ORGANIZAÇÃO PAN-AMERICANA DA SAÚDE). Métodos de investigação epidemiológica em doenças transmissíveis. Brasília, 1997. V.1, 116p.

PARÉ, J. et al. Interpretation of an indirect fluorescent antibody test for diagnosis of Neospora sp. infection in cattle. Journal of Veterinary Diagnostic Investigation, v.7, p.273-275, 1995. Disponível em: <http://jvdi.org/cgi/reprint/7/2/273.pdf>. Acesso em: 16 nov. 2010

PERINO L.J. et al. Effects of various risk factors on plasma protein and serum immunoglobulin concentrations of calves at post partum hours 10 and 24 . American Journal of Veterinary Research, v.56, p.1144-1148, 1995.

PRITCHARD, G. Milk antibody testing in cattle. In Practice, v.23, p.542-549, 2001. Disponível em: <http://inpractice.bmj.com/ content/23/9/542.abstract>. Acesso em: 17 nov. 2010. doi:10.1136/ inpract.23.9.542.

SANCHEZ, J. et al. A longitudinal study of gastrointestinal parasites in Canadian dairy farms. The value of an indirect Ostertagi ostertagi ELISA as monitoring tool. Veterinary Parasitology, v.107, p.209-226, 2002. Disponível em: <http://www.sciencedirect.com/ science?_ob=ArticleURL\&_udi=B6TD7-468SSWP-2 >. Acesso em: 17 nov. 2010. doi:10.1016/S0304-4017(02)00158-9.

SCHARES, G. et al. Adaptation of a commercial ELISA for the detection of antibodies against Neospora caninum in bovine milk. Veterinary Parasitology, v.120, p.55-63, 2004. Disponível em: $<\mathrm{h} \mathrm{t} \mathrm{t} \mathrm{p} \mathrm{:} \mathrm{/} \mathrm{/} \mathrm{w} \mathrm{w} \mathrm{w.} \mathrm{s} \mathrm{c} \mathrm{i} \mathrm{e} \mathrm{n} \mathrm{c} \mathrm{e} \mathrm{d} \mathrm{i} \mathrm{r} \mathrm{e} \mathrm{c} \mathrm{t} \mathrm{.} \mathrm{c} \mathrm{o} \mathrm{m} \mathrm{/}$ science?_ob=ArticleURL\&_udi=B6TD7-4BMCB33-1>. Acesso em: 16 nov. 2010. doi:10.1016/j.vetpar.2003.11.016.

STENLUND, S. et al. Serum antibody profile and reproductive performance during two consecutive pregnancies of cows naturally infected with Neospora caninum. Veterinary Parasitology, v.85, p.227-234, 1999. Disponível em: <http://www.sciencedirect.com/ science?_ob=ArticleURL\&_udi=B6TD7-3X4W5VT-F>. Acesso em: 17 nov. 2010. doi:10.1016/S0304-4017(99)00120-X.

THURMOND, M.C.; HIETALA, S.K. Culling associated with Neospora caninum infection in dairy cows. American Journal of Veterinary Research, v.57, p.1559-1562, 1996. 